\title{
Immobilization on a Nanomagnetic Co/C Surface Using ROM Polymerization: Generation of a Hybrid Material as Support for a Recyclable Palladium Catalyst
}

\author{
Alexander Schätz, \\ Institute for Organic Chemistry, University of Regensburg, Universitätsstr. 31, D-93053 \\ Regensburg, Germany
}

Toby R. Long,

Department of Chemistry, University of Kansas, 1251 Wescoe Hall Drive, Lawrence, KS, 66045, USA and The University of Kansas Center for Chemical Methodologies and Library Development (KU-CMLD), 2121 Simons Drive, West Campus, Lawrence, KS, 66047, USA

\section{Robert N. Grass,}

Institute for Chemical and Bioengineering, Department of Chemistry and Applied Biosciences, ETH Zurich Wolfang-Pauli-Strasse 10, CH-8093 Zurich, Switzerland

\section{Wendelin J. Stark,} Institute for Chemical and Bioengineering, Department of Chemistry and Applied Biosciences, ETH Zurich Wolfang-Pauli-Strasse 10, CH-8093 Zurich, Switzerland

Paul R. Hanson*, and Department of Chemistry, University of Kansas, 1251 Wescoe Hall Drive, Lawrence, KS, 66045, USA and The University of Kansas enter for Chemical Methodologies and Library Development (KU-CMLD), 2121 Simons Drive, West Campus, Lawrence, KS, 66047, USA

\section{Oliver Reiser}

Institute for Organic Chemistry, University of Regensburg, Universitätsstr. 31, D-93053

Regensburg, Germany

\section{Abstract}

\begin{abstract}
A novel hybrid material is reported as support for a recyclable palladium catalyst via surface immobilization of a ligand onto Co-based magnetic nanoparticles (NPs). A standard "click" reaction is utilized to covalently attach a norbornene tag $(\mathrm{Nb}-\mathrm{tag})$ to the surface of the carbon coated cobalt NPs. The hybrid magnetic nanoparticles are produced by initiating polymerization of a mixture containing both $\mathrm{Nb}$-tagged ligand $\left(\mathrm{Nb}\right.$-tagged $\left.\mathrm{PPh}_{3}\right)$ and $\mathrm{Nb}$-tagged carbon coated cobalt NPs. In turn, the norbornene units are suitably functionalized to serve as ligands for metal catalysts. A composite material is thus obtained which furnishes a loading that is one order of magnitude higher than the value obtained previously for the synthesis of functionalized $\mathrm{Co} / \mathrm{C}$ nanopowders. This allows for its application as a hybrid support with high local catalyst concentrations, as demonstrated for the immobilization of a highly active and recyclable palladium complex for Suzuki-Miyaura cross-coupling reactions. Due to the explicit magnetic moment of the cobalt- NPs, the overall magnetization of this organic/inorganic framework is significantly higher than of polymer coated iron oxide nanoparticles with comparable metal content, hence, its rapid separation from the reaction mixture and recycling via an external magnetic field is not hampered by the functionalized polymer shell.
\end{abstract}

() 2010 WILEY-VCH Verlag GmbH \& Co. KGaA, Weinheim

*Fax: (+49)941-943-4121, oliver.reiser@ chemie.uni-regensburg.de, phanson@ku.edu. 


\section{Introduction}

Interest in magnetic nanomaterials for applications in electronics ${ }^{[1]}$ as well as in medical ${ }^{[2]}$ and chemical ${ }^{[3]}$ research has steadily increased in recent years. Hence, strategies were developed to coin diverse inorganic and organic frameworks with magnetic properties. Groundbreaking studies in the area of catalysis disclosed materials such as silica, carbon or polymers doped with magnetic nanoparticles. ${ }^{[4]}$ In recent years, many reports focused on defined core/shell assemblies based on super-paramagnetic iron oxide nanoparticles (SPION), such as magnetite. ${ }^{[3,5]}$ Indeed, the lack of magnetic remanence in this material in the absence of an external magnetic field is especially beneficial for the dispersability of the nanomagnets. However, this advantage is accompanied by a relatively low saturation moment of ferrites $\left(M_{\mathrm{S} \text {,bulk }} \leq 92 \mathrm{emu} \mathrm{g}^{-1}\right)$, which is, compared to bulk, usually by far lower in the nano-sized matter, due to partial surface oxidation, and sometimes further diminished through the need for a protective shell. ${ }^{[6]}$ As a consequence, hybrid materials that rely on iron oxide nanoparticles demand a high metal content, e.g., for effective magnetic separation, thus limiting the fraction of other functional material in the composite and their total load capacity. Nanoparticles derived from pure metals exhibit superior magnetic properties to oxides, but their synthesis had been limited to small scale operations. ${ }^{[7,8]}$ Recently, Grass et al. ${ }^{[9]}$ reported on a continuous process, in which substantial amounts (> $30 \mathrm{~g} \mathrm{~h}^{-1}$ ) of carbon coated ferromagnetic nanoparticles are accessible via reducing flame-spray pyrolysis. ${ }^{[10]}$ Despite the comparatively thin graphene layer $(1 \mathrm{~nm})$, the intrinsically pyrophoric metal cores exhibit a remarkable thermal and chemical stability ${ }^{[11]}$ and moreover, the carbon layer deposited on the cobalt core has no detrimental effect on the magnetization $(158 \mathrm{emu} / \mathrm{g}$ ). Therefore, $\mathrm{Co} / \mathrm{C}$-nanoparticles seem to be a suitable cornerstone for magnetic hybrid materials that ensure high local catalyst loadings. ${ }^{[12]}$

\section{Results and Discussion}

Ring-opening metathesis polymerization (ROMP)-derived polymers and oligomers have been of great interest as scaffolds for the immobilization of a plethora of reagents, scavengers and catalysts, ${ }^{[13,14]}$ since the high loadings (e.g., $7.3 \mathrm{mmol} \mathrm{g}^{-1}[13 \mathrm{f}]$ ) obtained with such resins have clear benefits. ${ }^{[15]}$ ROMP-derived polymers can be tuned to be soluble in a variety of organic solvents, thus, they enable a fully homogeneous process.

Alternatively cross-linking can be utilized to yield ROMPgels with favorable properties when compared to traditional resins. Despite the rate-enhancement achieved in solutionphase chemistry, such scaffolds require an additional solvent for selective precipitation out of the reaction mixture. A second solvent can be an environmental drawback in industrial processes and recycling through precipitation/filtration is not necessarily quantitative. In contrast, $\mathrm{Co} / \mathrm{C}$-nanomagnets allow for their simple and rapid separation via magnetic decantation but feature only a very limited loading $(0.1 \mathrm{mmol} / \mathrm{g}) .{ }^{\text {[9] }}$ Although a low catalyst loading can be advantageous, e.g. when spatial interactions between chiral catalytic moieties shall be suppressed, ${ }^{[16]}$ it is usually outbalanced by the problems associated with the sheer mass of support necessary.

\subsection{Synthesis and Characterization of Co/C-ROMPgel}

Buchmeiser ${ }^{[17]}$ Grubbs ${ }^{[18]}$ and Whiteside, ${ }^{[19]}$ have demonstrated ring-opening metathesis (ROM) polymerization on silica surfaces, while Buchmeiser and Barrett have also reported ROM polymerization on polystyrene resins. ${ }^{[20]}$ Barrett has demonstrated an increase in load in developing ROMP-spheres, ${ }^{[20]}$ while Roberts has used ROM polymerization on resins to capture Nb-tagged $N$-hydroxy succinimide in the development of a high-load, resin- 
immobilized acylation reagent. ${ }^{[21]}$ This complies with the extraordinary stability of the Co/ C-NPs and prevents leaching of the nanoparticles from the polymer branches. ROMPderived oligomers have also been used as surfactants to stabilize maghemite nanoparticles,

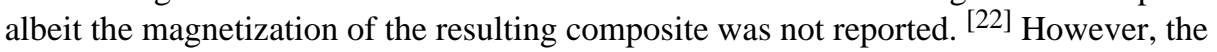
covalent attachment of ROMPgel on magnetic nanoparticles is unprecedented.

In a first step, we utilized a copper(I)-catalyzed alkyne/azide cycloaddition (CuAAC) reaction ("click" reaction) ${ }^{[23]}$ to graft propargylated norbornene derivative $\mathbf{3}$ onto azide functionalized Co/C-NPs 2 (Scheme 1).

The synthesis of the azide-tagged particles was achieved in a concise two-step reaction based on covalent attachment of diazonium compounds on the graphene layers as described previously. $\left.{ }^{[9 a}, 24\right]$ An azide-loading of $0.1 \mathrm{mmol} \mathrm{g}^{-1}$ was thus obtained as determined by elemental microanalysis. In our strategy, we used the immobilized alkene $\mathbf{3}$ as a means of loading triphenylphosphine-functionalized norbornenes $6^{[25]}$ onto the nanoparticle surface. Briefly, a closed microwave vessel containing alkene modified Co/C-NPs 4 was placed in a tempered $\left(60{ }^{\circ} \mathrm{C}\right)$ ultrasound bath and the nanopowder was dispersed in degassed $\mathrm{CH}_{2} \mathrm{Cl}_{2}$ via sonication under an inert atmosphere (argon). A solution of Ru-complex 5 (1.0 equiv. with respect to $\mathrm{Co} / \mathrm{C}$-immobilized alkene 4, $2 \mathrm{~mol} \%$ with respect to $\mathrm{PPh}_{3}$-norbornene derivative 6) was added to generate a ruthenium carbene species on the nanoparticle surface by ring-opening metathesis with the norbornene units in 4 . ROM polymerization ${ }^{[26]}$ was then carried out by adding 6 under conditions otherwise suitable for the formation of a 50 mer. During the course of the reaction, a voluminous, black gel was formed, leaving only little residual solvent. Assuming that all $\mathrm{Co} / \mathrm{C}$-nanoparticles were coated with the available amount of oligomer, one would expect a Co-content of approximately $33 \%$ in the resulting hybrid material, a value which was confirmed by elemental microanalysis. TEM images affirmed that the $\mathrm{Co} / \mathrm{C}$-particles were embedded in a polymer matrix, thus "diluting" the otherwise densely packed clusters, a characteristic associated with the high magnetic remanence of the metal cores (Figure 1). Also, no evidence of cross linking was observed in agreement with earlier studies in which metathesis between an immobilized norbornene derivative and dissolved olefins was carried out. [27]

To ensure that the polymer did not only encapsulate the nanomagnets but was covalently attached to the carbon shell, we ran a control experiment utilizing azide-functionalized $\mathrm{Co} /$ C-NPs 2 instead of alkene-modified particles 4. In contrast to the previous observation, no gel was formed and the nanoparticles precipitated after the ROM polymerization while the oligomer remained in solution until precipitated from $\mathrm{MeOH}$. The swelling behavior of the Co/C-ROMPgel was found to be in line with the general properties of ROMPgels, showing a pronounced volume increase in THF and $\mathrm{CH}_{2} \mathrm{Cl}_{2}$ whereas solvents such as $\mathrm{MeOH}$ or Et 2 O did not provoke a significant effect. ${ }^{[28]}$

The morphology of the composite was clearly distinct from both parent materials as observed in scanning electron micrographs (SEM, Figure 2). To this end, the aforementioned ROMP oligomer obtained from polymerization in the presence of azidefunctionalized Co/C-NPs $\mathbf{2}$ rather than $\mathbf{4}$ was analyzed next to unmodified Co/Cnanoparticles $\mathbf{1}$. In addition, the specimen stub was coated with a silver dispersion prior to deposition of Co/C-ROMPgel 7 to prevent the accumulation of static electric charge on the sample and to display its inherent magnetic field (Figure 2,c). Energy dispersive X-ray (EDX) confirmed the presence of phosphor in the hybrid material (Figure 2,d). The fraction of phosphor was assessed via elemental microanalysis (3.45\%), corresponding to $1.1 \mathrm{mmol}$ $\mathrm{g}^{-1}$ P-loading. Hence, approximately $30 \%$ of the hybrid material consists of triphenylphosphine (TPP). The immobilized TPP was expected to coin the nanocomposite 
with the ability to serve as separable reagent/scavenging agent ${ }^{[30]}$ or ligand, i.e. for the formation of a recyclable palladium complex.

\subsection{Catalysis with a Co/C-ROMPgel Immobilized Pd-Complex}

Several examples of palladium complexes anchored on different magnetic iron oxide nanoparticles have been reported in the past years. ${ }^{[5,31]}$ However, highly functionalized architectures that relied on stabilized ferrite cores were naturally less susceptible to magnetic separation.

Doping of such matrices with palladium, an objective that is typically achieved by mixing a metal source together with the ligand-functionalized scaffold (Scheme 2), is prone to further diminish the mass magnetization. Figure 3 highlights the magnetization of composite $\mathbf{8}$, which was measured via vibrating sample magnetometer (VSM) and found to be $34 \mathrm{emu} / \mathrm{g}$, a value consistent with the mass percentage of ferromagnetic cobalt in the sample. This level is comparable to surfactant stabilized SPIONs, however, polymer or silica coated iron oxide NPs, materials, which resemble $\mathbf{8}$ in terms of durability, exhibit significantly lower magnetization. [6]

To examine the catalytic efficacy of Pd-catalyst $\mathbf{8}$, we subjected it to several consecutive Suzuki-Miyaura cross-coupling reactions ${ }^{[32]}$ of aryl halides with phenylboronic acids (Table 1), a reaction that has been used as benchmark for palladium nanocatalysts. ${ }^{[3]}$ As it is common in such reactions, iodides were transformed more rapidly than bromides or chlorides, hence, good to very good yields were achieved for a number of phenylboronic acids when iodobenzene was chosen as substrate (entries 1,3,4, and 6). To ensure that the immobilized Pd-complex represents the catalytic active species rather than free metal that is dissociated from the polymer bound ligand under reaction conditions $\left(65^{\circ} \mathrm{C}\right)$ and leaching into the homogeneous phase, we designed the following control experiment: A mixture of catalyst $\mathbf{8}$, sodium carbonate and THF/water mixture at given ratios (Table 1) was stirred at the reaction temperature for $2 \mathrm{~h}$. Subsequently, catalyst $\mathbf{8}$ was retracted with the aid of an external magnet and the hot supernatant was transferred into a new vessel before phenylboronic acid $\mathbf{1 0}$ and phenyliodide $\mathbf{9}$ were added to the solution. After further $2 \mathrm{~h}$ of stirring at $65^{\circ} \mathrm{C}$, no conversion of reactants into biphenyl 11 was detected by ${ }^{1} \mathrm{H}$ NMR. Thus, it appeared that no significant contribution to the efficacy of the catalytic system originated from dissolved palladium-species. In addition, AAS-analysis of the aqueous layer revealed a rather insignificant Pd-content (1.9 ppm). The performance of this novel hybrid catalyst was comparable to results obtained elsewhere with Pd-phosphine-complexes grafted on heterogenous supports comprising e.g. different polymers or nanoparticles. ${ }^{[5,33,34]}$ Importantly, catalyst $\mathbf{8}$ was quantitatively recovered after each reaction and reused in the next run, proving the suitablitiy of the new Co/C-ROMPgel as a high capacity support that can be readily recovered by magnetic separation.

\section{Conclusions}

The immanent advantage of Co/C-ROMPgel as a novel hybrid material, e.g. for catalyst immobilization, lies in the combined advantage of high loading ROMP technology and the ease of recycling via magnetic decantation that is provided by the ferromagnetic metal core nanoparticles. The remarkable chemical and thermal stability of the graphene layers surrounding the nanoparticles ranks with the durability of the polymer itself. This composite might be suited as alternative to assemblies that rely on iron oxides as magnetic core material. 


\section{Experimental Section}

\section{General Procedures and Reagents}

All air and moisture sensitive reactions were carried out in flame- or oven-dried glassware under argon atmosphere using standard gastight syringes, canellas, and septa. THF, $\mathrm{CH}_{2} \mathrm{Cl}_{2}$ and toluene were purified by passage through a Solv-Tek ${ }^{[35]}$ (www.solvtek.com) purification system employing activated $\mathrm{Al}_{2} \mathrm{O}_{3}$ and degassed with argon. Flash column chromatography was performed with $\mathrm{SiO}_{2}$ (Sorbent Technologies 30930M-25, Silica Gel $60 \AA, 40-63 \mu \mathrm{m}$ ). Thin layer chromatography was performed on silica gel $60 \mathrm{~F} 254$ plates. Visualization of TLC spots was effected using $\mathrm{KMnO}_{4}$ stain. ${ }^{1} \mathrm{H}$ and ${ }^{13} \mathrm{C}$ NMR spectra were recorded on a Bruker DRX-400 NMR spectrometer operating at 400 and $100 \mathrm{MHz}$ respectively. The nanoparticles were analyzed by FTIR spectroscopy (1\% in $\mathrm{KBr}$ using a Tensor 27 Spectrometer, Bruker Optics equipped with a diffuse reflectance accessory, DiffusIR, Pike Technologies), atom absorption spectroscopy (Varian SpectrAA 220FS), elemental microanalysis (LECO CHN-900), transmission electron microscopy (CM30 STPhilips, $\mathrm{LaB}_{6}$ cathode, operated at $300 \mathrm{kV}$ point resolution $\sim 4 \AA$ ), scanning electron microscopy (Hitachi S-2700 equipped with a quartz PCI digital capture) and magnetic hysteresis susceptibility (vibrating sample magnetometer, VSM, Princeton Measurements Corporation, model 3900). The synthesis of carbon coated cobalt nanoparticles 1 and (4-exo(bicyclo[2.2.1]hept-5-en-2-yl)phenyl)diphenylphosphine $\mathbf{6}$ has been described elsewhere. ${ }^{[9,36]}$ The nanomagnets were azide-functionalized according to literature precedents. ${ }^{24]}$ All other commercially available compounds were used as received. Second generation Grubbs catalyst 5 was provided by Materia Inc. and used without further purification. Deuterated solvents were purchased from Cambridge Isotope laboratories.

\section{Norbornene-Functionalized Co/C-Nanoparticles 4}

The azide-tagged carbon coated cobalt nanobeads 2 ( $400 \mathrm{mg} ; 0.1 \mathrm{mmol} \mathrm{g}{ }^{-1}$ azide-loading) were suspended in degassed toluene $(3 \mathrm{~mL})$ by the use of an ultrasonic bath (Sonorex RK 255 H-R, Bandelin) before 5-((prop-2-yn-1-yloxy) methyl)bicyclo[2.2.1]hept-2-ene 3 (130 $\mathrm{mg}, 0.8 \mathrm{mmol})$, triethylamine $(20 \mu \mathrm{L}, 0.12 \mathrm{mmol})$ and $\mathrm{CuI}(5 \mathrm{mg}, 0.03 \mathrm{mmol})$ were added. The resulting slurry was sonicated for $48 \mathrm{~h}$ at ambient temperature under an argon atmosphere. The nanobeads were recovered from the reaction mixture with the aid of a neodymium based magnet (N48, W-12-N, Webcraft GmbH, side length $12 \mathrm{~mm}$ ) and washed with toluene $(6 \times 5 \mathrm{~mL})$. Each washing step consisted of suspending the particles in the solvent, ultrasonication $(5 \mathrm{~min})$ and retracting the particles from the solvent by the aid of the magnet. After the last washing step the particles were dried in vacuo to yield $430 \mathrm{mg}$ of 4 . IR $\left(v / \mathrm{cm}^{-1}\right): 2928,2817,2097,1693,1598,1505,1404,1377,1253,1214,1175,1096$, $1013,824,71681$; elemental microanalysis: $13.57 \% \mathrm{C}, 0.69 \% \mathrm{H}, 1.18 \% \mathrm{~N}$.

\section{$\mathrm{PPh}_{3}$-Functionalized Co/C-ROMPgel 7}

$200 \mathrm{mg}$ of norbornene-functionalized Co/C-nanoparticles 4 were dispersed in $\mathrm{CH}_{2} \mathrm{Cl}_{2}$ (2 $\mathrm{mL}$ ) by sonication in a sealed microwave reaction vessel under argon atmosphere (30 $\mathrm{min})$. A solution of Grubbs II catalyst $(17 \mathrm{mg}, 0.02 \mathrm{mmol})$ in $\mathrm{CH}_{2} \mathrm{Cl}_{2}(1 \mathrm{~mL})$ was injected and the ultrasound bath tempered to $60{ }^{\circ} \mathrm{C}$ while sonication of the reaction mixture continued (30 min). (4-exo-(bicyclo[2.2.1]hept-5-en-2-yl)phenyl)diphenylphosphine 6 (353 mg, $1.0 \mathrm{mmol}$ ) was added and the dispersion was subjected to sonication at $60^{\circ} \mathrm{C}$ for $2 \mathrm{~h}$. Within $50 \mathrm{~min}$ the formation of voluminous black gel was observed. After $2 \mathrm{~h}$ the reaction was quenched and a single, jelly-like lump was removed from the reaction vessel, crushed and dried in vacuo to yield $490 \mathrm{mg}$ of 7 . IR $\left(\mathrm{v} / \mathrm{cm}^{-1}\right)$ : 2929, 2859, 1644, 1584, 1475, 1432, 1400, 1303, 1259 , 1177, 1089, 1064, 962, 894, 852, 760, 691, 655; elemental microanalysis: 55.95\% C; 4.59\% $\mathrm{H}, 0.47 \% \mathrm{~N}, 3.45 \% \mathrm{P}$. 


\section{Pd-PPh 3 -Functionalized Co/C-ROMPgel 8}

$200 \mathrm{mg}$ of $\mathrm{PPh}_{3}$-functionalized Co/C-ROMPgel 7 was allowed to swell in $\mathrm{CH}_{2} \mathrm{Cl}_{2}(2 \mathrm{~mL})$ under sonication at $60^{\circ} \mathrm{C}$ under an atmosphere of argon (30 min) before $\mathrm{Pd}(\mathrm{OAc})_{2}(40 \mathrm{mg}$, $0.18 \mathrm{mmol}$ ) was added to the reaction vessel. Sonication was maintained for additional $2 \mathrm{~h}$ before the magnetic ROMPgel was isolated from the reaction mixture by the aid of an external magnet and dried in vacuo to yield $212 \mathrm{mg}$ of $\mathbf{8}$. IR $\left(\mathrm{v} / \mathrm{cm}^{-1}\right): 2982,2360,2155$, 1053, 1033, 1014, 696, 674, 664, 652; elemental microanalysis: $49.23 \%$ C; 4.06\% H; $0.43 \%$ N. AAS analysis: $57.3 \mathrm{mg}$ nanoparticles 8 were extracted with $10 \mathrm{ml} \mathrm{HNO}_{3}$ (conc), the sample was further diluted with water (1:100) and subjected to AAS to reveal a palladium content of $0.48 \mathrm{mmol}$ palladium per gram nanoparticle $\mathbf{8}$.

\section{Acknowledgments}

This work was supported by the IDK NANOCAT (Elitenetzwerk Bayern) and the Atlantis program (EU/FIPSE). Dr. F. Krumeich (ETH Zurich) and Heather Shinogle (KU) are acknowledged for carrying out SEM and TEM analyses, Dr. H.-P. Hächler (ETH Zurich) for VSM measurements. We thank Materia Inc. for providing Grubbs II catalyst. This work was supported by the International Doktorandenkolleg NANOCAT (Elitenetzwerk Bayern) and the Deutsche Forschungsgemeinschaft (Re 948/8-1, “GLOBUCAT"), the EU-Atlantis program CPTUSA-20064560, the National Institute of General Medical Science (Center in Chemical Methodologies and Library Development at the University of Kansas, KU-CMLD, NIH P50 GM069663 and NIH-STTR R41 GM076765) with additional funds from the State of Kansas.

\section{References}

1. Huber DL. Small. 2005; 1:482. [PubMed: 17193474]

2. a) Lee H, Lee E, Kim DK, Jang NK, Jeong YY, Jon S. J. Am. Chem. Soc. 2006; 128:7383. [PubMed: 16734494] b) Xu ZP, Zeng QH, Lu GQ, Yu AB. Chem. Eng. Sci. 2006; 61:1027.c) Huh YM, Jun YW, Song HT, Kim S, Choi JS, Lee JH, Yoon S, Kim KS, Shin JS, Suh JS, Cheon J. J. Am. Chem. Soc. 2005; 127:12387. [PubMed: 16131220] d) Song HT, Choi JS, Huh YM, Kim S, Jun YW, Suh JS, Cheon J. J. Am. Chem. Soc. 2005; 127:9992. [PubMed: 16011350] e) Benderbous S, Corot C, Jacobs P, Bonnemain B. Acad. Radiol. 1996; 3:292.f) Pankhurst QA. B T Technol J. 2006; 24:33.g) Kohler H, Sun C, Fichtenholtz A, Gunn J, Fang C, Zhang M. Small. 2006; 2:785. [PubMed: 17193123] h) Kim J, Kim HS, Lee N, Kim T, Kim H, Yu T, Song IC, Moon WK, Hyeon T. Angew. Chem. Int. Ed. 2008; 47:8438.i) Park K, Lee S, Kang E, Kim K, Choi K, Kwon IC. Adv. Funct. Mater. 2009; 19:1553.j) Gleeson O, Tekoriute R, Gun'ko YK, Connon SJ. Chem. Eur. J. 2009; 15:5669. [PubMed: 19388038]

3. a) Shokouhimehr M, Piao Y, Kim J, Jang Y, Hyeon T. Angew. Chem. Int. Ed. 2007; 119:7169.b) Liu J, Peng X, Sun W, Zhao Y, Xia W. Organometallics. 2008; 10:3933.c) Sobal NS, Hilgendorff M, Möhwald H, Giersig M. Nano Lett. 2002; 2:621.d) Ceylan S, Friese C, Lammel C, Mazac K, Kirschning A. Angew. Chem. Int. Ed. 2008; 47:8950.e) Hu A, Yee GT, Lin W. J. Am. Chem. Soc. 2005; 127:12486. [PubMed: 16144385] f) Gleeson O, Tekoriute R, Gun'ko YK, Connon SJ. Chem. Eur. J. 2009; 15:5669. [PubMed: 19388038] g) Chouhan G, Wang D, Alper H. Chem. Commun. 2007:4809.h) Lu AH, Salabas EL, Schüth F. Angew. Chem. 2007; 119:1242.Angew. Chem. Int. Ed. 2007; 46:1222.

4. a) Lu A-H, Li WC, Kiefer A, Schmidt W, Bill E, Fink G, Schüth F. J. Am. Chem. Soc. 2004; 126:8616. [PubMed: 15250690] b) Lu A-H, Schmidt W, Matoussevitch N, Bönnemann H, Spliethoff B, Tesche B, Bill E, Kiefer W, Schüth F. Angew. Chem. Int. Ed. 2004; 43:4303.c) Lu AH, Li W, Matoussevitch N, Spliethoff B, Pennemann HB, Schüth F. Chem. Commun. 2005:98.d) Sen T, Sebastianelli A, Bruce IJ. J. Am. Chem. Soc. 2006; 128:7130. [PubMed: 16734444] e) Ge J, Huynh T, Hu Y, Yin Y. Nano Lett. 2008; 8:931. [PubMed: 18237148] e) Michalek F, Lagunas A, Jimeno C, Pericàs MA. J Mater Chem. 2008; 18:4692.

5. a) Stevens PD, Fan J, Gardimalla HMR, Yen M, Gao Y. Org. Lett. 2005; 7:2085. [PubMed: 15901140] b) Duanmu C, Saha I, Zheng Y, Goodson BM, Gao Y. Chem. Mater. 2006; 18:5973.c) Abu-Reziq R, Alper H, Wang D, Post ML. J. Am. Chem. Soc. 2006; 128:5279. [PubMed: 16608364] d) Gill CS, Long W, Jones CW. Catal. Lett. 2009; 131:425.e) Rosario-Amorin D, Wang X, Gaboyard M, Clerac R, Nlate S, Heuze K. Chem. Eur. J. 2009; 15:12636. [PubMed: 19839017] 
f) Hua D, Tang J, Dai L, Pu Y, Cao X, Zhu X. J Nanosci Nanotechnol. 2009; 9:6681. [PubMed: 19908584] g) Arai T, Sato T, Kanoh H, Kaneko K, Oguma K, Yanagisawa A. Chem. Eur. J. 2008; 14:882. [PubMed: 17994600] h) Jin M-J, Lee D-H. Angew. Chem. 2010; 122:1137.

6. a) Butterworth MD, Illum L, Davis SS. Colloids Surf, A. 2001; 179:93.b) Sun Y, Duan L, Guo Z, Mu YD, Ma M, Xu L, Zhang Y, Gu N. J. Magn. Magn. Mater. 2005; 285:65.c) Deng Y-H, Wang CC, Hu J-H, Yang W-L, Fu S-K. Colloids Surf, A. 2005; 262:87.d) Lee J, Lee Y, Youn JK, Na HB, Yu T, Kim H, Lee S-M, Koo Y-M, Kwak JH, Park HG, Chang HN, Hwang M, Park J-G, Kim J, Hyeon T. Small. 2008; 4:143. [PubMed: 18189246]

7. a) Saito Y. Carbon. 1995; 33:979.b) Scott JHJ, Majetich SA. Phys. Rev B. 1995; 52:12564.c) Jiao J, Seraphin S, Wang X, Withers JC. J. Appl. Phys. 1996; 80:103.

8. a) Wang ZH, Choi CJ, Kim BK, Kim JC, Zhang ZD. Carbon. 2003; 41:1751.b) Flahaut E, Agnoli F, Sloan J, O'Connor C, Green MLH. Chem. Mater. 2002; 14:2553.

9. a) Grass RN, Athanassiou EK, Stark WJ. Angew. Chem. Int. Ed. 2007; 46:4909.b) Herrmann IK, Grass RN, Mazunin D, Stark WJ. Chem. Mater. 2009; 21:3275.c) Grass RN, Stark WJ. J. Mater. Chem. 2006; 16:1825.c) Wittmann S, Schätz A, Grass RN, Stark WJ, Reiser O. Angew. Chem. Int. Ed. 2010; 49:1867.

10. Stark WJ, Madler L, Maciejewski M, Pratsinis SE, Baiker A. Chem. Commun. 2003:588.

11. a) Koehler FM, Rossier M, Waelle M, Athanassiou EK, Limbach LK, Grass RN, Günther D, Stark WJ. Chem. Commun. 2009:4862.b) Rossier M, Koehler FM, Athanassiou EK, Grass RN, Aeschlimann B, Günther D, Stark WJ. J. Mater. Chem. 2009; 19:8239.

12. Fuhrer R, Athanassiou EK, Luechinger NA, Stark WJ. Small. 2009; 5:383. [PubMed: 19180549]

13. a) Preishuber-Pflügl P, Buchacher P, Eder E, Schitter RM, Stelzer F. J. Mol. Catal A. 1998; 133:151.b) Moore JD, Herpel RH, Lichtsinn JR, Flynn DL, Hanson PR. Org. Lett. 2003; 5:105. [PubMed: 12529116] c) Zhang M, Moore JD, Flynn DL, Hanson PR. Org. Lett. 2004; 6:2657. [PubMed: 15281737] d) Harned AM, Sherrill WM, Flynn DL, Hanson RR. Tetrahedron. 2005; 61:12093.e) Zhang M, Flynn DL, Hanson PR. J. Org. Chem. 2007; 72:3194. [PubMed: 17407352] f) Rolfe A, Probst D, Volp K, Omar I, Flynn D, Hanson PR. J. Org. Chem. 2008; 73:8785. [PubMed: 18937412] g) Harned AM, Zhang M, Vedantham P, Mukherjee S, Herpel RH, Flynn DL, Hanson PR. Aldrichimica Acta. 2005; 38:3.

14. Reviews: a) Barrett AGM, Hopkins BT, Köberling J. Chem. Rev. 2002; 102:3301. [PubMed: 12371886] b) Flynn DL, Hanson PR, Berk SC, Makara GM. Curr. Opin. Drug Discovery Dev. 2002; 5:571.

15. Ley SV, Schucht O, Thomas AW, Murray PJ. J. Chem. Soc., Perkin Trans. 1999:1251.

16. Schätz A, Hager M, Reiser O. Adv. Funct. Mater. 2009; 19:2109.

17. a) Buchmeiser MR, Seeber G, Mupa M, Bonn GK. Chem. Mater. 1999; 11:1533.b) Buchmeiser MR, Sinner F, Mupa M, Wurst K. Macromolecules. 2000; 33:32.c) Gatschelhofer C, Magnes C, Pieber TR, Buchmeiser MR, Sinner FM. J. Chromatogr. A. 2005; 1090:81. [PubMed: 16196136]

18. Rutenberg IM, Scherman OA, Grubbs RH, Jiang W, Garfunkel E, Zhenan B. J. Am. Chem. Soc. 2004; 126:4062. [PubMed: 15053568]

19. Kim NY, Jeon NL, Hoi IS, Takami S, Harada Y, Finnie KR, Girolami GS, Nuzzo RG, Whitesides GM, Laibinis PE. Macromolecules. 2000; 33:2793.

20. Barrett AGM, Cramp SM, Roberts RS. Org. Lett. 1999; 7:1083.

21. Roberts RS. J. Comb. Chem. 2005; 7:21. [PubMed: 15638475]

22. Belfield KD, Zhang L. Chem. Mater. 2006; 18:5929.

23. Tornøe, CW.; Meldal, M. In: LebI, M.; Houghten, RA., editors. American Peptide Symposium; American Peptide Society, Kluwer Academic Publishers; San Diego, CA. 2001. p. 263b) Rostovtsev VV, Green LG, Fokin VV, Sharpless KB. Angew. Chem. Int. Ed. 2002; 41:2596.c) Tornøe CW, Christensen C, Meldal M. J. Org.Chem. 2002; 67:3057. [PubMed: 11975567]

24. a) Schätz A, Grass RN, Stark WJ, Reiser O. Chem. Eur. J. 2008; 14:8262. [PubMed: 18666291] b) Schätz A, Grass RN, Kainz Q, Stark WJ, Reiser O. Chem. Mater. 2010; 22:305.

25. a) ROMPgel-supported $\mathrm{PPh}_{3}$ : Årstad E, Barrett AGM, Hopkins BT, Köbberling J. Org. Lett. 2002; 4:1975. [PubMed: 12027661] b) Harned AM, Song He H, Toy PH, Flynn PHDL, Hanson PR. J. Am. Chem. Soc. 2005; 127:52. [PubMed: 15631444] c) Yang Y-C, Luh T-YJ. Org. Chem. 2003; 68:9870. 
26. Scholl M, Ding S, Lee CW, Grubbs RH. Org. Lett. 1999; 1:953. [PubMed: 10823227]

27. a) Cuny GD, Cao J, Hauske JR. Tetrahedron Lett. 1997; 38:5237.b) Cao J, Cuny GD, Hauske JR. Mol. Diversity. 1998; 3:173.c) Week M, Jackiw JJ, Rossi RR, Weiss PS, Grubbs RH. J. Am. Chem. Soc. 1999; 121:4088.d) Barrett AGM, Cramp SM, Roberts RS. Org. Lett. 1999; 1:1083.e) Aarstad E, Barrett AGM, Hopkins BT, Koebberling J. Org. Lett. 2002; 4:1975. [PubMed: 12027661] Roberts RSJ. Comb. Chem. 2005; 7:21.

28. Santini R, Griffith MC, Qi M. Tetrahedron Lett. 1998; 39:8951.

29. The $\mathrm{Cu}$-signal in the EDX-spectrum is rather originated by the copper grid, on which the sample was supported during measurement, than residual copper from the "click"-reaction. No traces of the ruthenium based ROMP-catalyst 5 appeared in any spectrum.

30. a) McKinley SV, Rakshys JW. J. Chem. Soc., Chem. Commun. 1972:134.b) Bernard M, Ford WT. J. Org. Chem. 1983; 48:326.c) Tunoori AR, Dutta D, Georg GI. Tetrahedron Lett. 1998; 39:8751.d) Regen SL, Lee DP. J. Org. Chem. 1975; 40:1669.e) Charette AB, Boezio AA, Janes MK. Org. Lett. 2000; 2:3777. [PubMed: 11101417] f) Westman J. Org. Lett. 2001; 3:3745. [PubMed: 11700128]

31. a) Stevens PD, Li G, Fan J, Yenb M, Gao Y. Chem. Commun. 2005:4435.b) Zheng Y, Stevens PD, Gao Y. J. Org. Chem. 2006; 71:537. [PubMed: 16408961] c) Baruwati B, Reddy KM, Manorama SV, Singh RK, Parkash O. Appl. Phys. Lett. 2004; 85:2833.d) Guin D, Baruwati B, Manorama SV. J. Mol. Catal. A Chem. 2005; 242:26.e) Guin D, Baruwati B, Manorama SV. Org. Lett. 2007; 9:1419. [PubMed: 17323965] f) Baruwati B, Guin D, Manorama SV. Org. Lett. 2007; 9:5377. [PubMed: 18020449] g) Ceylan S, Friese C, Lammel C, Mazac K, Kirschning A. Angew. Chem. Int. Ed. 2008; 47:8950.h) Liu J, Peng X, Sun W, Zhao Y, Xia C. Org. Lett. 2008; 10:3933. [PubMed: 18722455] i) Lv G, Mai W, Jin R, Gao L. Synlett. 2008; 9:1418.

32. a) Miyaura N, Yamada K, Suzuki A. Tetrahedron Lett. 1979; 20:3437.c) Miyaura N, Suzuki A. Chem. Rev. 1995; 95:2457.d) Barder TE, Walker SD, Martinelli JR, Buchwald SL. J. Am. Chem. Soc. 2005; 127:4685. [PubMed: 15796535]

33. a) Stevens PD, Li GF, Fan JD, Yen M, Gao Y. Chem. Commun. 2005:4435.b) Narayanan R, ElSayed MA. J. Am. Chem. Soc. 2003; 125:8340. [PubMed: 12837106] c) Gopidas KR, Whitesell JK, Fox MA. Nano Lett. 2003; 3:1757.d) Kim SW, Kim M, Lee WY, Hyeon T. J. Am. Chem. Soc. 2002; 124:7642. [PubMed: 12083902]

34. a) Uozumi Y, Nakai Y. Org. Lett. 2002; 4:2997. [PubMed: 12182608] b) Bergbreiter DE, Liu Y-S. Tetrahedron Lett. 1997; 38:7843. c) Uozumi Y, Danjo H, Hayashi T. Tetrahedron Lett. 1998; 39:8303. d) Uozumi Y, Danjo H, Hayashi T. J. Org. Chem. 1999; 64:3384. [PubMed: 11674453] e) Uozumi Y, Watanabe T. J. Org. Chem. 1999; 64:6921. [PubMed: 11674711] f) Kim J-W, Kim J-H, Lee D-H, Lee Y-S. Tetrahedron Lett. 2006; 27:4745. Review: g) Uozumi Y. Bull. Chem. Soc. Jpn. 2008; 81:1183.

35. Grubbs RH, Rosen RK, Timmers FJ. Organometallics. 1996; 15:1518.

36. Andrew M, He H, Song T, Patrick H, Flynn DL, Hanson PR. J. Am. Chem. Soc. 2005; 127:52. [PubMed: 15631444] 

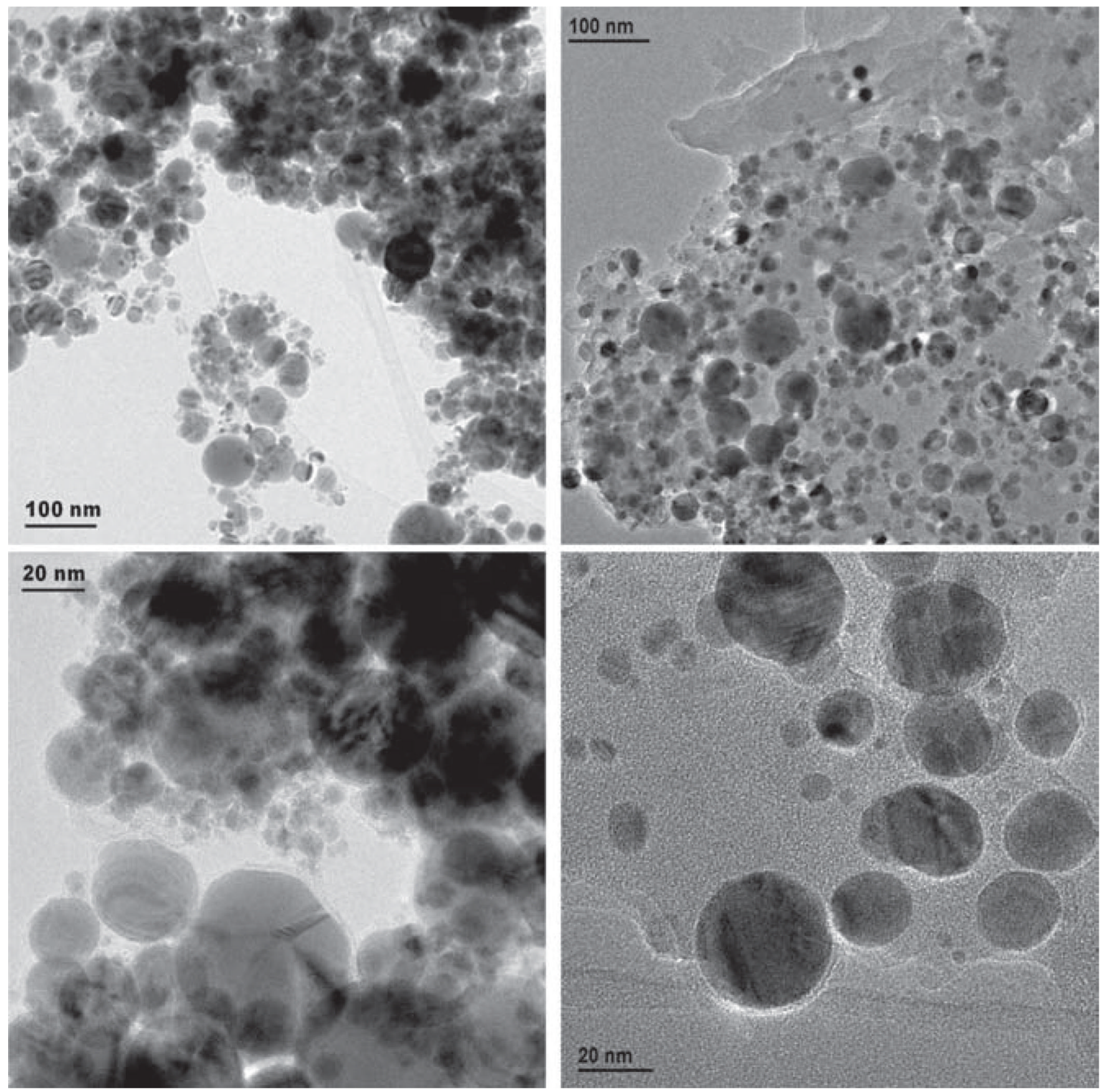

Figure 1.

TEM images of Co/C-nanoparticles 1 (left) and Co/C-ROMPgel 7 (right) at different resolutions; bar size: $100 \mathrm{~nm}$ (top) and $20 \mathrm{~nm}$ (bottom). 

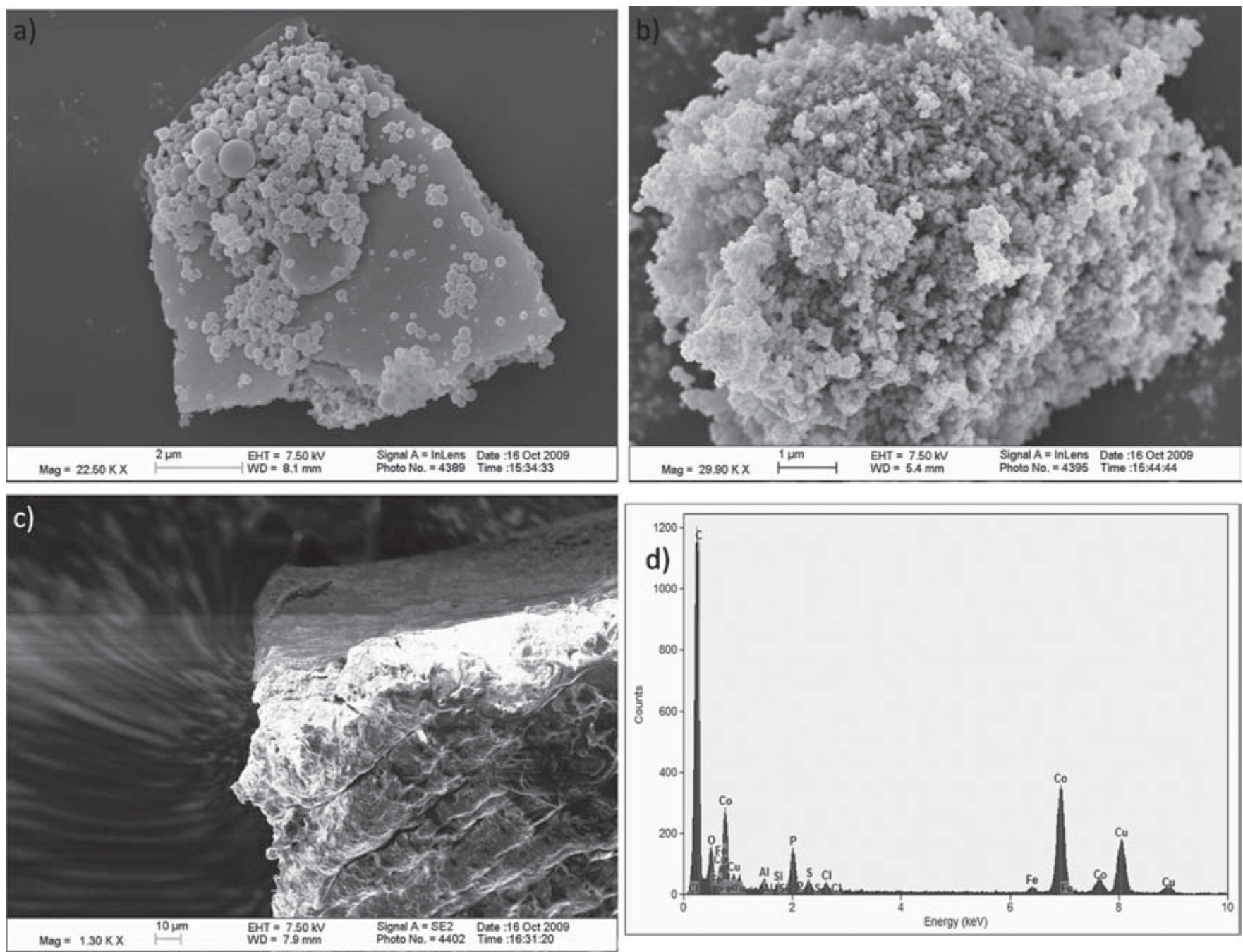

Figure 2.

SEM images of ROMPgel (a), Co/C-nanoparticles 1 (b), and Co/C-ROMPgel 7 (c); bar size: $2 \mu \mathrm{m}$ (a), $1 \mu \mathrm{m}$ (b), and $10 \mu \mathrm{m}$ (c); EDX-spectrum of 7 (d). ${ }^{[29]}$ 

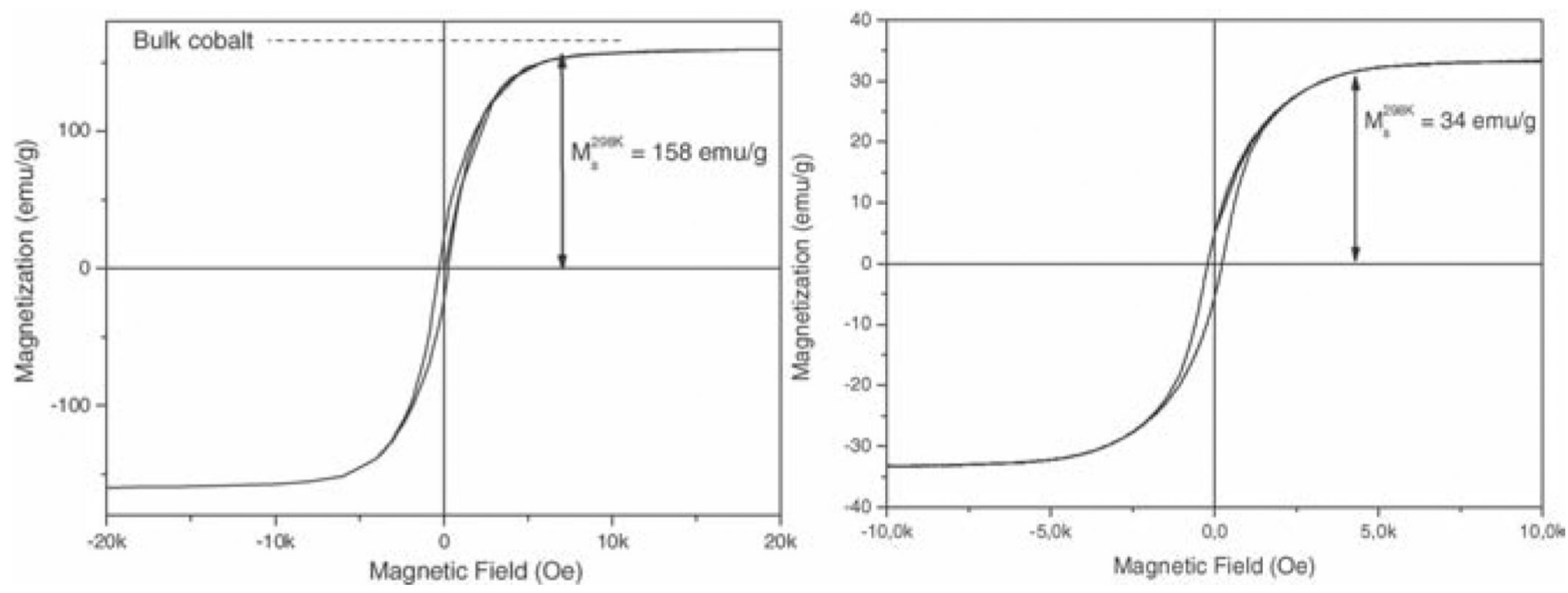

Figure 3.

Magnetization curve of Co/C-nanoparticles 1 (left) and Pd@ Co/C-ROMPgel 8 containing $30 \% 1$ (right) obtained by VSM at room temperature. The saturation magnetization of the carbon coated cobalt NPs was close to bulk cobalt $\left(158 \mathrm{emu} \mathrm{g}^{-1}\right)$, whereas the hybrid material reached $34 \mathrm{emu}^{-1}$. 
1. $\mathrm{HCl}, \mathrm{NaNO}_{2}$
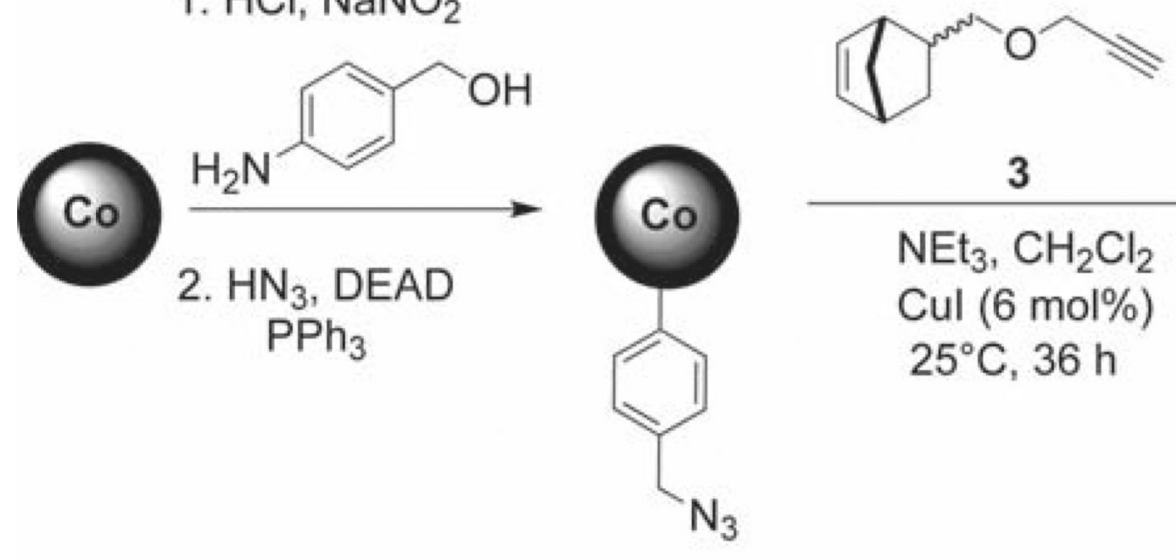

1

2
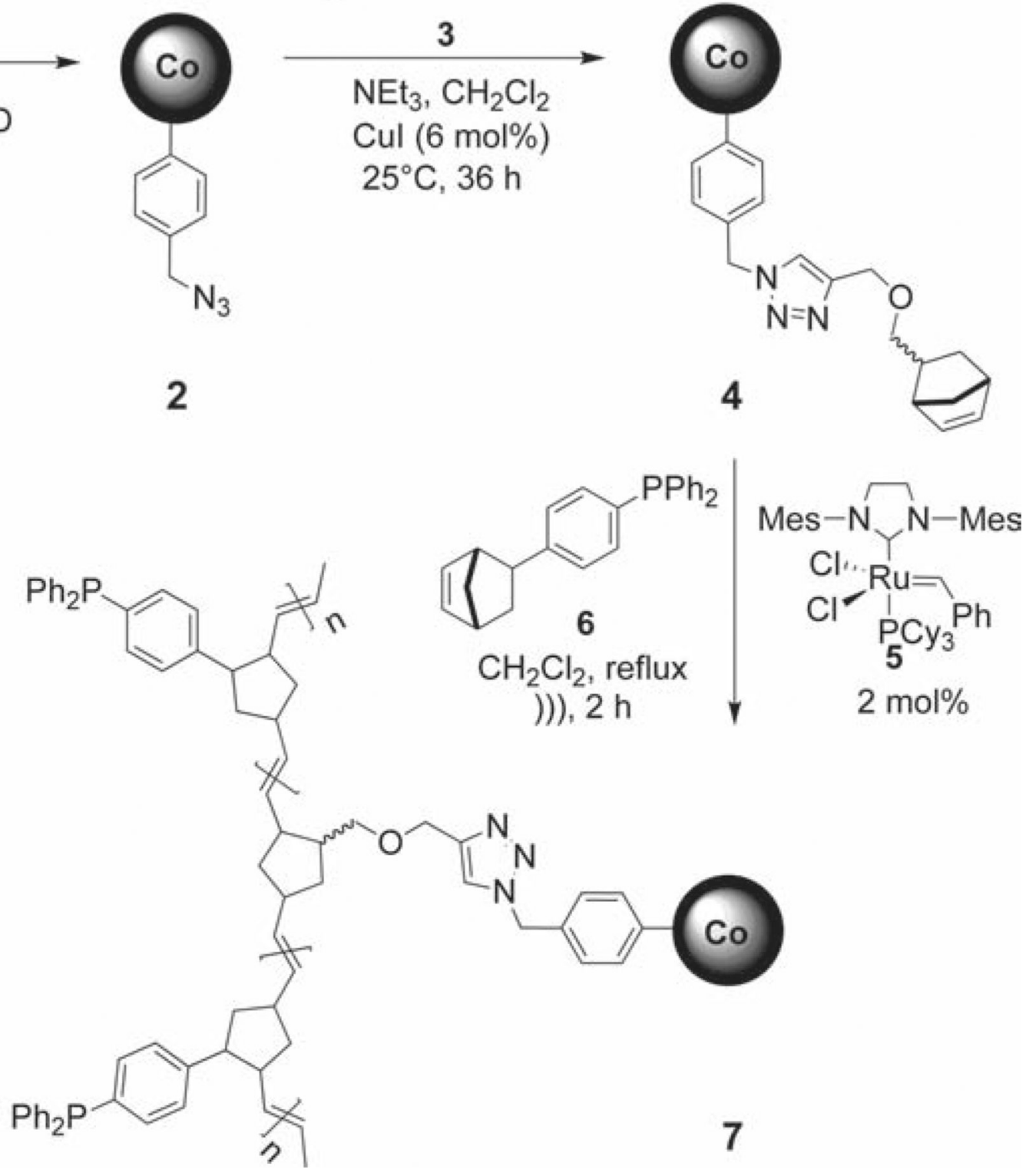

Scheme 1.

Functionalization of azide-tagged Co/C-nanoparticles $\mathbf{2}$ with alkene $\mathbf{3}$ via copper(I)catalyzed CuAAC ("click" chemistry) and subsequent ring-opening metathesis polymerization to covalently grafted ROMPgel on the magnetic nanobeads. 

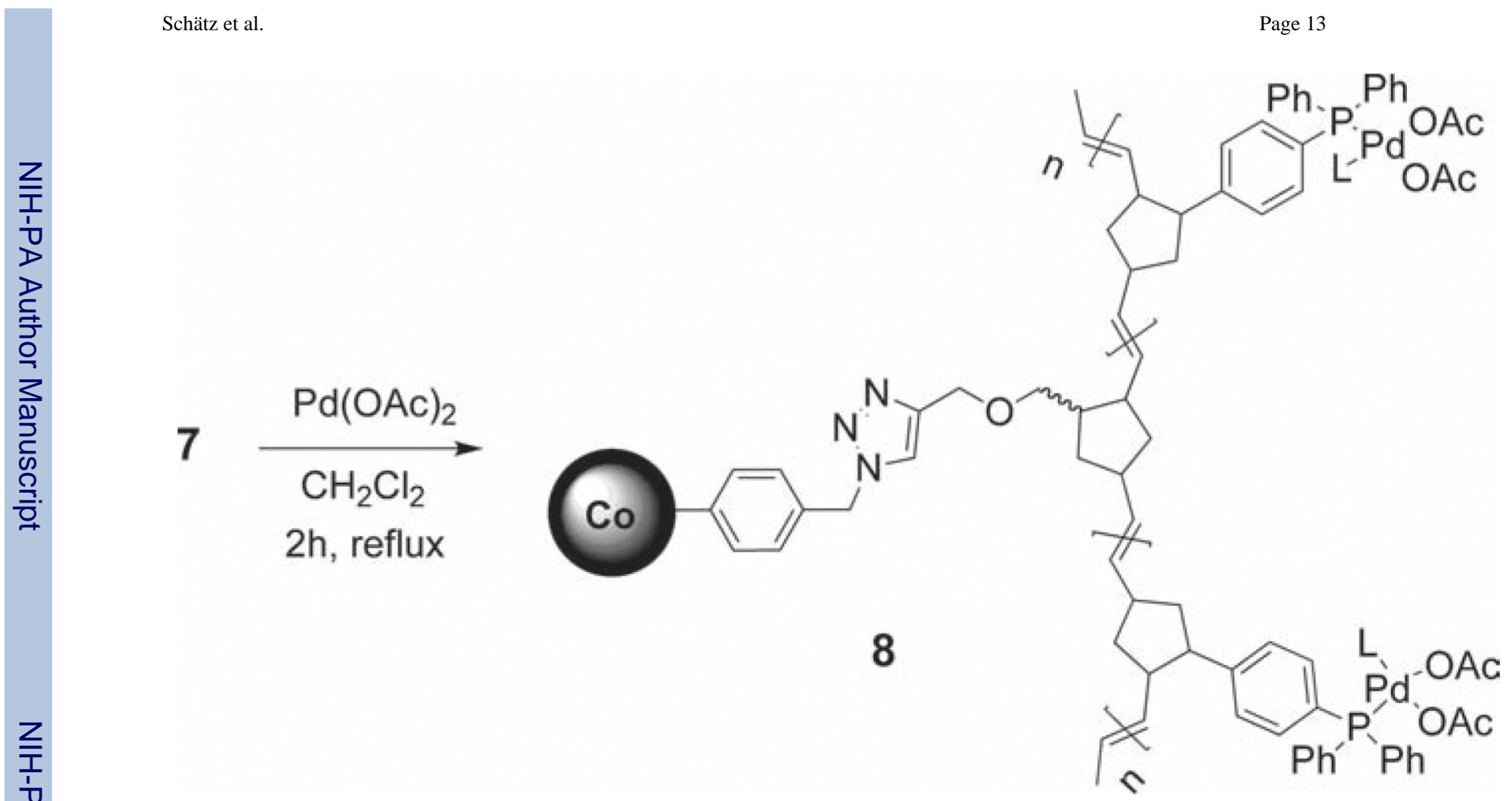

Scheme 2.

Formation of a heterogeneous Palladium-complex on $\mathrm{PPh}_{3}$-functionalized $\mathrm{Co} / \mathrm{C}$-ROMPgel 7. The Pd-content of $\mathbf{8}$ was assessed by AAS $\left(0.48 \mathrm{mmol} \mathrm{g}^{-1}\right)$. 


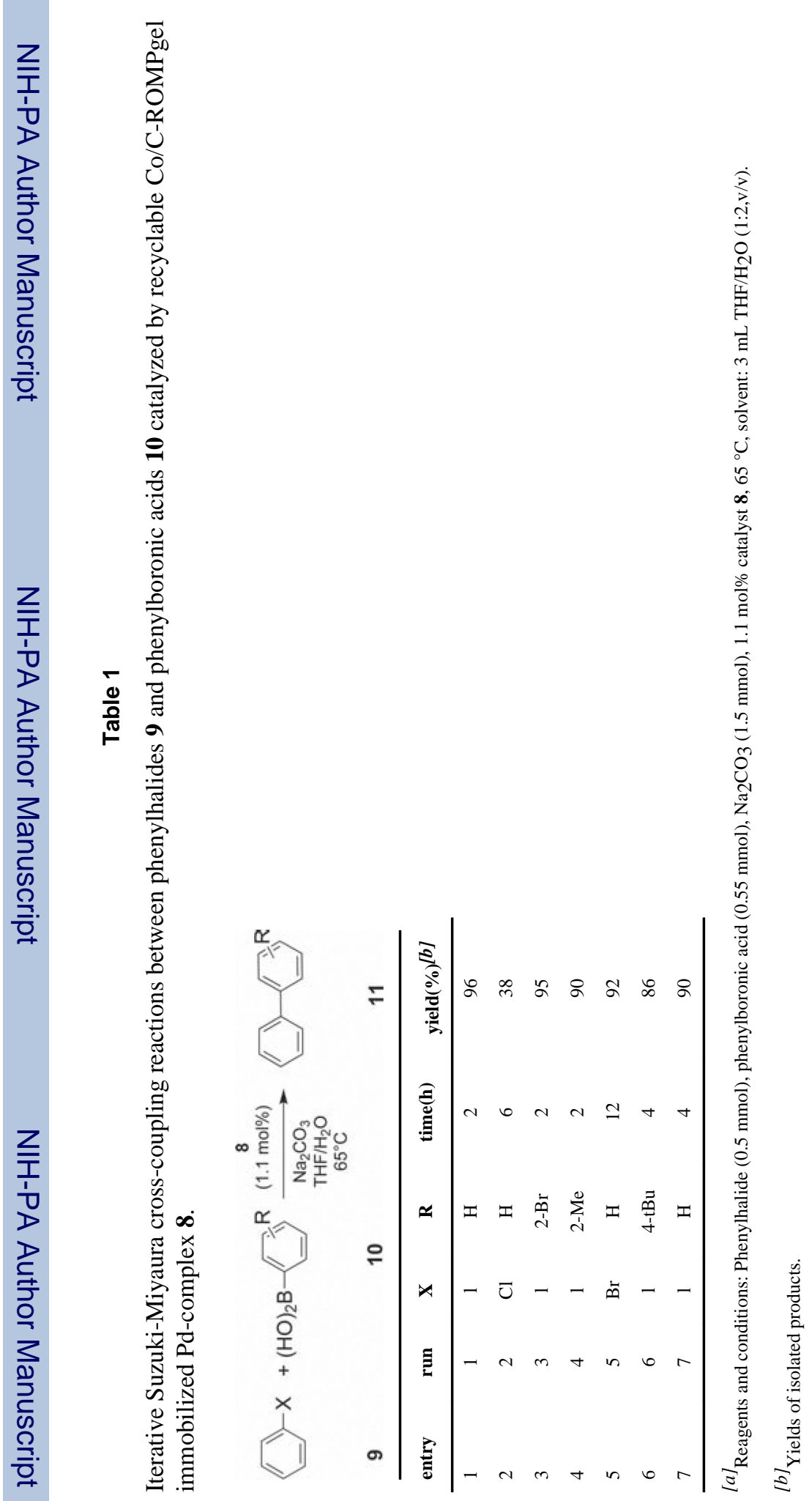

Adv Funct Mater. Author manuscript; available in PMC 2012 February 3. 